\title{
Comparative Effectiveness of Flotation Technique at Varying Conditions for Beneficiation of Itakpe and Agbaja Iron Ores
}

\author{
Serah Akande, Oladunni O. Alabi, E. O. Ajaka, and Temitope A. Olatunji
}

\begin{abstract}
Itakpe and Agbaja iron ores are part of prominent iron deposits in Nigeria, yet studies on their beneficiation via froth flotation are relatively limited. Thus, this research investigated comparatively the flotation behaviour of both ores at varied pulp $\mathrm{pH}$, particle size, and collector type. The ores were also examined using Energy Dispersive X-ray Fluorescence Spectroscopy, Petrological, and fractional sieve size analyses. Fifty (50) kg sample each of the ores was sourced for the research. Then, size fractions $(63,75$, and $125 \mu \mathrm{m})$ of each ore were prepared and subjected to froth flotation using different collectors; Potassium Amyl Xanthate (PAX), Sodium Ethyl Xanthate (SEX), and Oleic Acid, at varying pulp $\mathrm{pH}$ ranging from 9-11. From the results obtained Itakpe iron ore assayed $36.18 \% \quad \mathrm{Fe}_{2} \mathrm{O}_{3}$ and contains predominantly haematite, sillimanite, and quartz while Agbaja iron ore contains chiefly, quartz and haematite, and assayed 40.6\% $\mathrm{Fe}_{2} \mathrm{O}_{3}$ alongside $1.505 \% \mathrm{P}_{2} \mathrm{O}_{5}$. The liberation sizes of both ores lie favourably in the range $-125+75 \mu \mathrm{m}$. Beneficiation studies carried out revealed that significant enrichment of both ores was actualized. Thus, it was established that Itakpe iron ore is best processed using PAX at pH 11 and particle size of $125 \mu \mathrm{m}$ yielding concentrates assaying $67.66 \% \quad \mathrm{Fe}_{2} \mathrm{O}_{3}$ at a recovery of $\sim 90 \%$ while for Agbaja iron ore, $\mathrm{PAX}$ at $\mathrm{pH} 9$ and particle size of $63 \mu \mathrm{m}$ is considered best to yield enriched concentrates assaying $65.5 \% \mathrm{Fe}_{2} \mathrm{O}_{3}$ at $52.5 \%$ recovery.
\end{abstract}

Index Terms-Agbaja and Itakpe Iron Ores, Comparative Effectiveness, Froth Flotation.

\section{INTRODUCTION}

Nigeria's iron ore exploration dated as far back as the 1970 s when viable quantities were discovered at Itakpe, Kogi State with an estimated reserve of 200 million tonnes [1]. Other deposits explored include Agbaja, Ajabanoko, and Chokochocko; Agbaja's reserve, estimated to be about 2 billion tonnes has been the largest so far [1][2]. These discoveries birthed processing plants such as the Ajaokuta Steel Company charged with processing iron ore sourced from Itakpe deposit into steel and other products [3]. The modalities of this industry entail several plants, among

Published on June 16, 2020

S. Akande, Department of Mining Engineering, Federal University of Technology, Akure, Ondo State, Nigeria

(e-mail: mrsserahak@gmail.com)

O. O. Alabi, Department of Metallurgical and Materials Engineering,

Federal University of Technology, Akure, Ondo State, Nigeria.

(e-mail: oladunni69alabi@yahoo.com)

E. O. Ajaka, Department of Mining Engineering, Federal University of

Technology, Akure, Ondo State, Nigeria

(e-mail: eoajaka@futa.edu.ng).

T. A. Olatunji, Department of Metallurgical and Materials Engineering, Federal University of Technology, Akure, Ondo State, Nigeria.

(e-mail: olatunjitopeamos@gmail.com) which is the froth flotation plant, yet to be developed to full capacity [4]. The chief beneficiation technique adopted to produce high-grade iron ore concentrates as feed for the agglomeration plant is froth flotation [5].

\section{A. Froth Flotation: A Method of Mineral Separation}

This is a physicochemical process that exploits the disparity in the surface properties of minerals; hydrophobicity and hydrophilicity, and the use of some chemical reagents to effect liberation [6]. Froth flotation can either be direct or reverse depending on the intended mineral of interest [7]. Froth flotation facilitates the beneficiation of intermediate and low-grade iron ores as alternatives to the depleting reserves of high-grade iron ore [8]. The majority of known iron ore deposits, including that of Itakpe and Agbaja, contain high siliceous minerals which are not fully liberated by the conventional gravity and magnetic techniques [9]. These minerals are found interlocked with the iron minerals, and liberation can only be effected at relatively fine sizes below 125 microns [10]. Since, the steel industry requires concentrates of bearable contents of silica, alumina, and other impurities, the need to employ sustainable, economical and effective beneficiation techniques, such as froth flotation, is imperative [11].

Experimental quantitative and qualitative data on the flotation behaviour of minerals are pertinent as they provide adequate information for the design and implementation of the processing plant. Flotation efficiency is influenced by parameters such as pulp $\mathrm{pH}$, collector type, pulp density, and particle size [7][12]. These parameters are varied with the sole aim of arriving at sets-of-conditions that enhance separation efficiency to yield high grade concentrates at optimal recovery. Therefore, this research analyses comparatively the flotation behaviour of Itakpe and Agbaja iron ores at varied process parameters. Consequently, technical data provided therein can be exploited in the development of efficient froth flotation routes that can be utilized at the Ajaokuta Steel Company.

\section{MATERIALS AND METHODS}

The procedural chart employed to achieve the objectives of this study is as shown in Fig. 1.

\section{A. Materials Sourcing}

Samples of Itakpe and Agbaja iron ores were sourced from the deposit areas located in Kogi State, Nigeria as shown in Fig. 2. Itakpe deposit is $7 \mathrm{~km}$ from Okene town having the geographical coordinates of latitude $7^{\circ} 36^{\prime} 52^{\prime \prime} \mathrm{N}$ and longitude $6^{\circ} 19^{\prime} 7^{\prime \prime} \mathrm{E}$ while Agbaja deposit is $15 \mathrm{~km}$ from 
Agbaja Central having geographical coordinates of latitude $7.9833^{\circ} \mathrm{N}$ and longitude $6.6500^{\circ} \mathrm{E}$ [2][9]. Fifty (50) $\mathrm{kg}$ representative sample was sourced from each deposit.

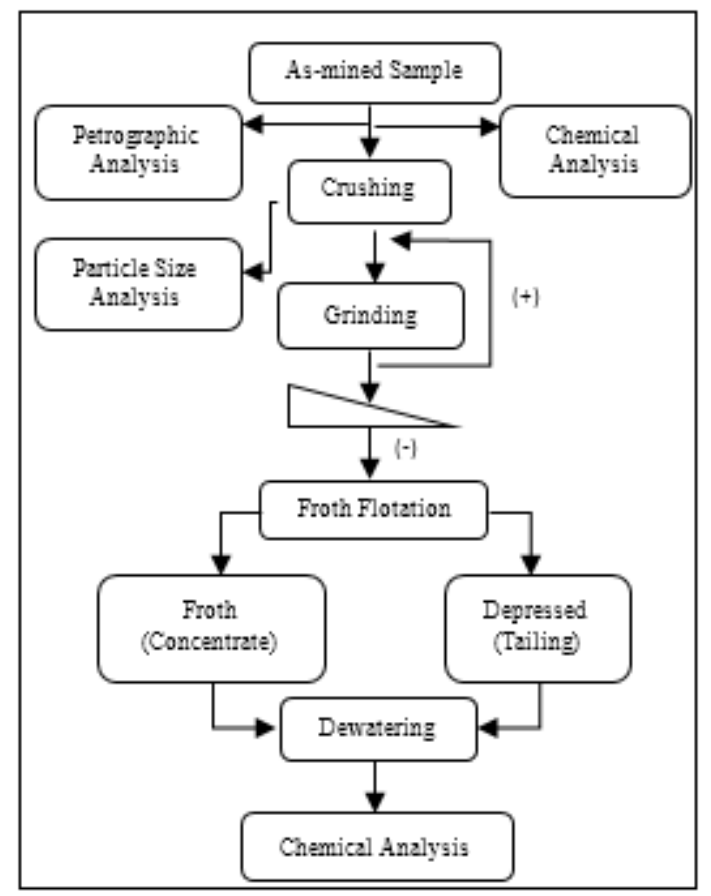

Fig. 1. Procedural flowchart employed

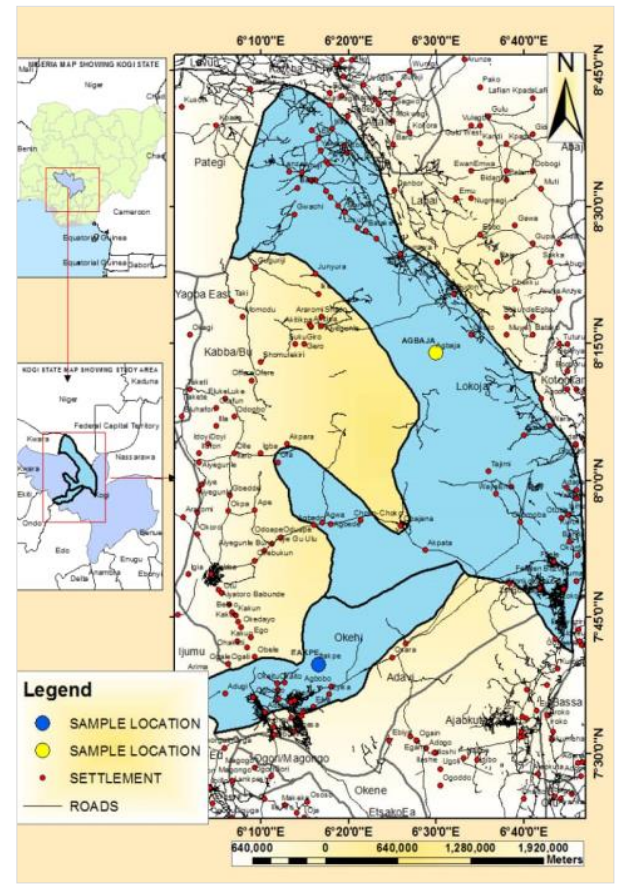

Fig. 2. Geographical map of the deposits

\section{B. Petrological Analysis}

Core Samples of the two ores were cut to standard sizes and their surfaces prepared by grinding using $500 \mu \mathrm{m}$ and $1000 \mu \mathrm{m}$ emery papers and then observed using the Leica Petrological Microscope (Model: EGB 100 DMX). The microstructural features of the two ores were analyzed under plane-polarized light at satisfactory magnifications to identify the mineral phases present therein.

\section{Chemical Composition Analysis}

The chemical compositions of the two ores were determined using Energy Dispersive X-ray Fluorescence Spectrometer (Model: PANanalytical Minipal 7). Then, 100 $\mathrm{g}$ of each ore was pulverized to about 200 mesh, $20 \mathrm{~g}$ sample each was weighed out, mixed with cellulose binder, and pelletized at a pressure of $10-15$ tons/in ${ }^{2}$. The formed pellets were desiccated and then analyzed using the prewarmed ED-XRF machine which identifies minor and major elements therein in percent concentration.

\section{Comminution and Particle Size Analysis}

The as-mined samples were crushed to $50 \mathrm{~mm}$ using a sledgehammer, and then further reduced to $5 \mathrm{~mm}$ using a Denver D12 laboratory jaw crusher. The crushed samples were charged into a roll crusher to be further reduced to $1000 \mu \mathrm{m}$ and then thoroughly homogenized. Fractional sieve analysis technique was adopted to assess the particle size distribution of the two ores and also ascertain their respective liberation sizes. A set-of-sieves arranged from $500-63 \mu \mathrm{m}$ as per $\sqrt{2}$ series with a pan placed at the bottom end was utilized. Then, $500 \mathrm{~g}$ sample was charged onto the upper sieve $(500 \mu \mathrm{m})$, and the set-of-sieves agitated for 30 minutes using an Automated Sieve Shaker (Model: Endecott AS400 control). The sieves were separated and the retained mineral particles on each measured to evaluate the cumulative percentage weight retained and passing for respective sieve sizes. Samples of the size fractions were also chemically characterized using ED-XRF.

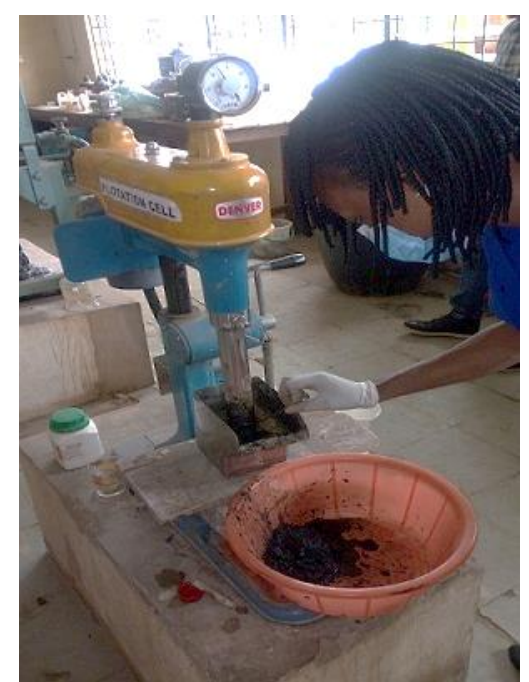

Fig. 3. Denver D12 flotation cell

\section{E. Concentration by Froth Flotation}

The essence of this test is to establish the parametric data required for the optimal recovery of iron minerals from both Itakpe and Agbaja iron ores by direct froth flotation technique. A Denver D12 Flotation Cell (Fig. 3) of capacity $800 \mathrm{ml}$ was employed. Five (5) $\mathrm{kg}$ crushed sample of each ore was pulverized to three size fractions; 63, 75, and 125

- $\mathrm{m}$. These sizes were selected having carried out particle size analyses of the two ores. Significant liberation was achieved for both ores at these sizes and they also fall within 250-45 $\mu \mathrm{m}$, which depicts the satisfactory size range for the flotation of iron ores (Wills and Napier-Munn, 2006). Then, 
$100 \mathrm{~g}$ of the $63 \cdot \mathrm{m}$ sample was mixed with $500 \mathrm{ml}$ of water and agitated for 2 minutes to form 16.7 wt. $\%$ solid pulp. The initial $\mathrm{pH}$ of the pulp was measured to be 8.2 using a $\mathrm{pH}$ meter. Thereafter, drops of sodium hydroxide (depressant) were added to adjust the $\mathrm{pH}$ to 9 followed by further agitation for 2 minutes. Then, two (2) drops of cornflour syrup (depressant) were added and the mixture was further agitated for 2 minutes, followed by the addition of two drops of potassium amyl xanthate, PAX (collector). The mixture was further stirred for 2 minutes after which 2 drops of methyl isobutyl carbinol (Frother) were added to ensure the stability of bubbles formed. The mixture was then stirred for another 2 minutes, thereby bringing the total agitation time to 10 minutes per process. The machine's air valve was opened to introduce air into the pulp, thereby causing the formation of froth on the pulp's surface. The froth containing the iron mineral was skimmed off into a container leaving behind the unwanted minerals. This process was repeated at $\mathrm{pH}$ of 9 and 11 while the other collectors, sodium ethyl xanthate (SEX) and oleic acid were used instead of PAX. The above procedure was then repeated for the $75 \mu \mathrm{m}$ and $125 \mu \mathrm{m}$ samples of both Itakpe and Agbaja ores. The resulting products (froth and depressed) were filtered and oven-dried for 24 hours. Then, samples were taken for chemical analysis.

\section{RESULTS}

The results obtained are presented in Tables I-II and Fig. 4-9.

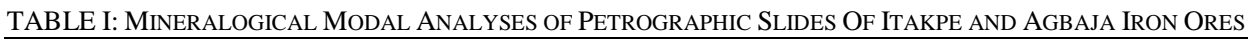

\begin{tabular}{ccccccc}
\hline \multirow{2}{*}{ Mineral } & \multicolumn{5}{c}{ No. of Counts } & \multirow{2}{*}{ Modal Count } \\
\cline { 2 - 6 } & \multicolumn{2}{c}{$1^{\text {st }}$ View } & $2^{\text {nd }}$ View & $3^{\text {rd }}$ View & Total & \\
\hline Quartz (Q) & 43 & 41 & 48 & 132 & 38 \\
Sillimanite & 10 & 1 & - & 11 & 3 & 59 \\
\hline Haematite and other Opaque minerals (H, Op) & 67 & 65 & 68 & 200 & 100 \\
\hline Total & 120 & 107 & 116 & 343 & 58 \\
\hline Agbaja Iron Ore & 53 & 49 & 147 & 42 \\
\hline Quartz (Q) & 45 & 37 & 40 & 111 & 100 \\
\hline Taematite and other Opaque Minerals (H, Op) & 37 & 32 & 88 & 89 & 258 & \\
\hline
\end{tabular}

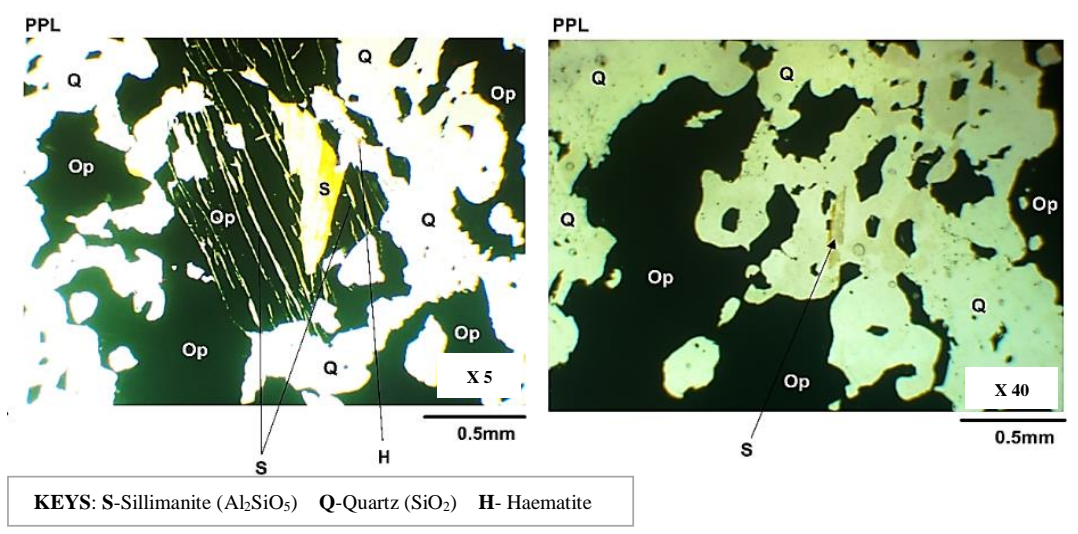

(a)
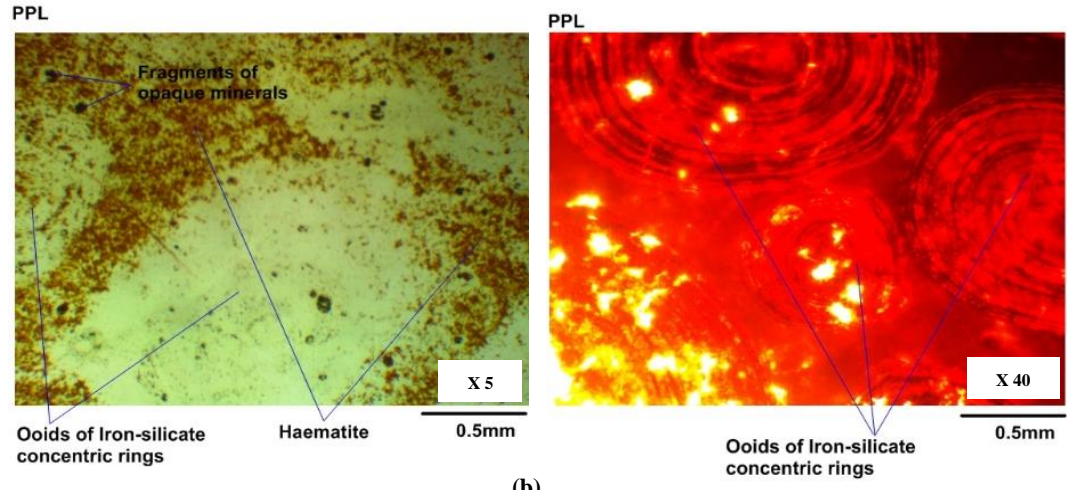

(b)

Ooids of Iron-silic concentric rings

Fig. 4. Photomicrographs of the crude sample of (a) Itakpe, and (b) Agbaja iron ores at different magnifications 
TABLE II: ED-XRF RESULT OF ITAKPE AND AGBAJA IRON ORES

\begin{tabular}{cccccccccc}
\hline \multicolumn{8}{c}{ Chemical composition of crude Itakpe iron } \\
\hline Compounds & $\mathrm{Al}_{2} \mathrm{O}_{3}$ & $\mathrm{SiO}_{2}$ & $\mathrm{~K}_{2} \mathrm{O}$ & $\mathrm{CaO}$ & $\mathrm{V}_{2} \mathrm{O}_{5}$ & $\mathrm{MnO}$ & $\mathrm{Fe}_{2} \mathrm{O}_{3}$ & $\mathrm{CuO}$ & $\mathrm{ZnO}$ \\
\% composition & 4.20 & 53.05 & 0.24 & 0.559 & 0.008 & 0.068 & 36.18 & 0.034 & 0.006 \\
\hline \multicolumn{8}{c}{ Chemical Composition of Crude Agbaja Iron Ore } \\
\hline Compounds & $\mathrm{Al}_{2} \mathrm{O}_{3}$ & $\mathrm{SiO}_{2}$ & $\mathrm{SO}_{3}$ & $\mathrm{P}_{2} \mathrm{O}_{5}$ & $\mathrm{~K}_{2} \mathrm{O}$ & $\mathrm{CaO}$ & $\mathrm{Cr}_{2} \mathrm{O}_{3}$ & $\mathrm{Fe}_{2} \mathrm{O}_{3}$ & $\mathrm{CuO}$ \\
\% Composition & 5.50 & 50.5 & 0.053 & 1.505 & 0.0089 & 0.1041 & 0.0193 & 40.6 & 0.025 \\
\hline
\end{tabular}
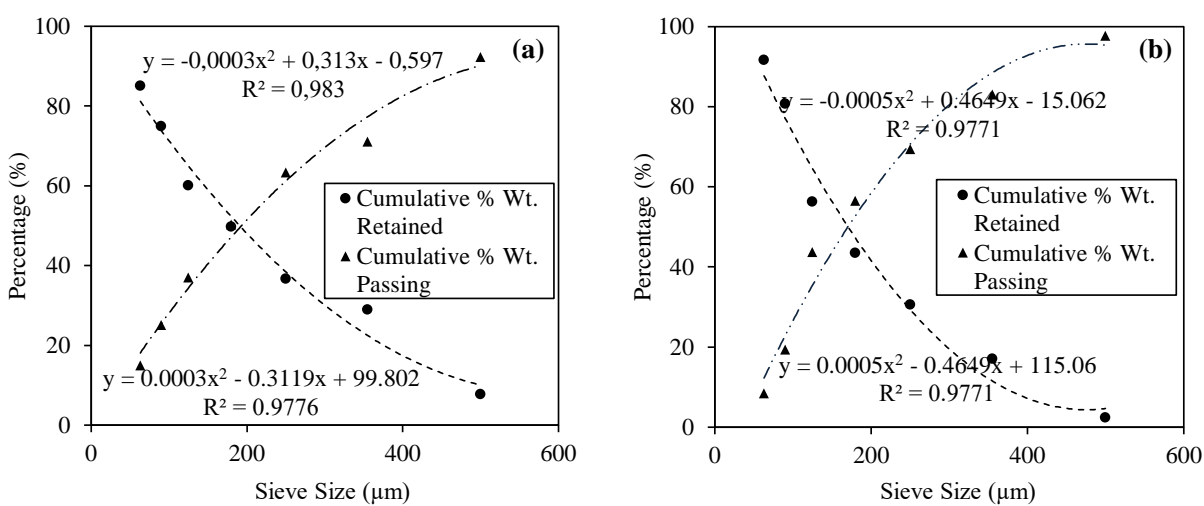

Fig. 5. The plot of cumulative $\%$ weight retained and passing of (a) Itakpe, and (b) Agbaja iron ores against sieve size ( $\mu \mathrm{m})$

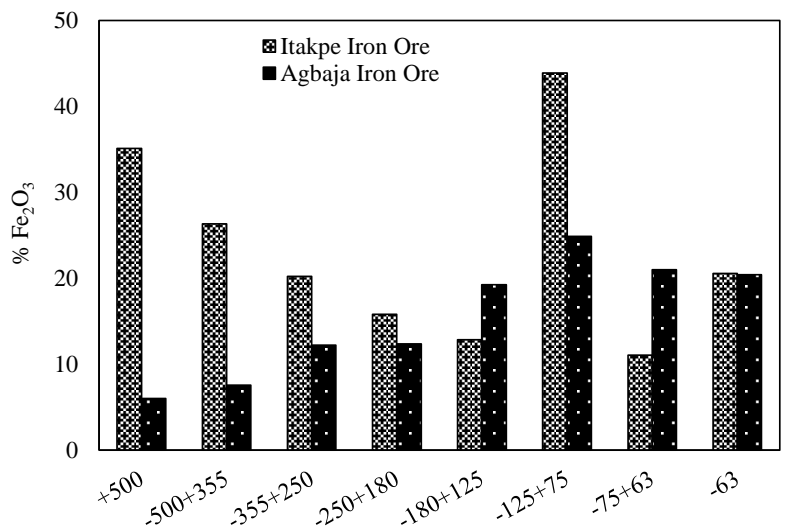

Sieve Size Range $(\mu \mathrm{m})$

Fig. 6. A comparative appraisal of the $\mathrm{Fe}_{2} \mathrm{O}_{3}$ content in size fractions of Itakpe and Agbaja iron ores
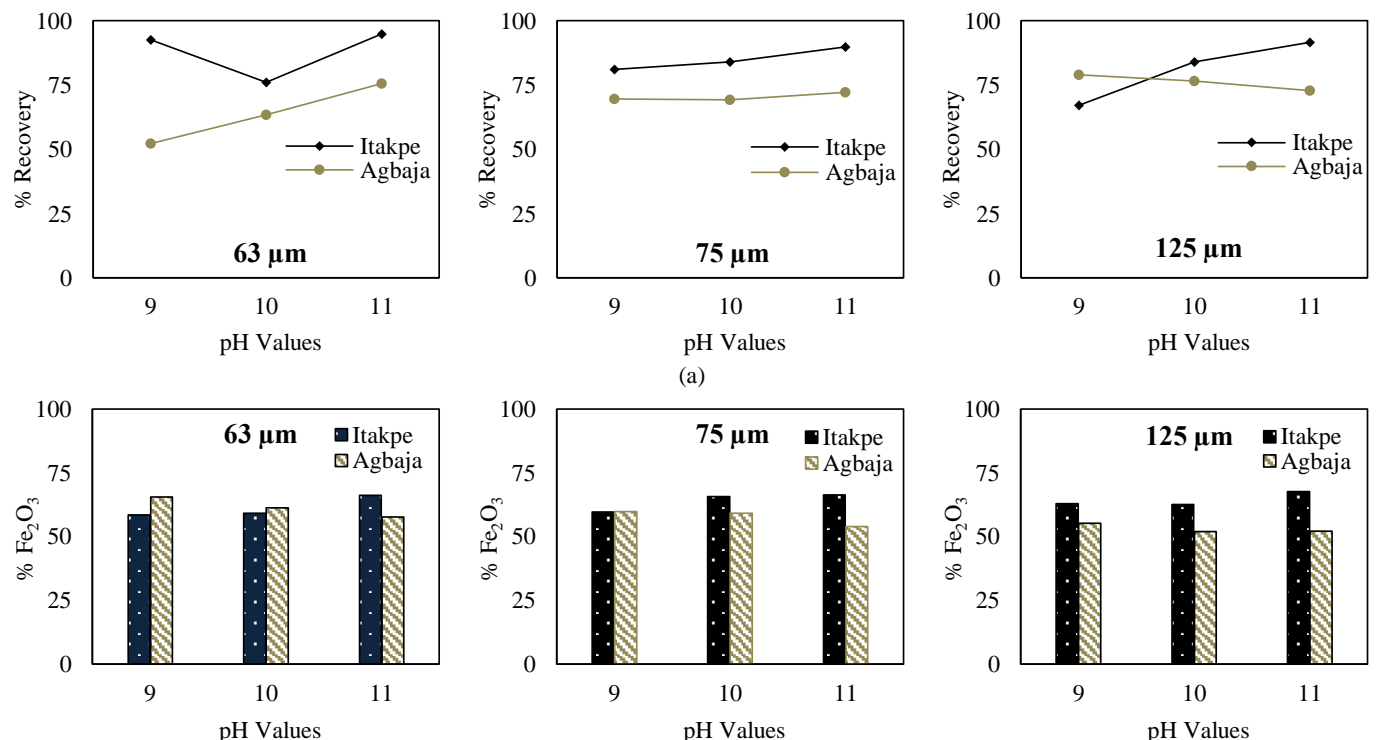

(b)

Fig. 7. Variation of (a) $\%$ recovery, and (b) assay $\left(\% \mathrm{Fe}_{2} \mathrm{O}_{3}\right)$ of PAX-processed Itakpe and Agbaja iron ores with $\mathrm{pH}$ values at different particle sizes 

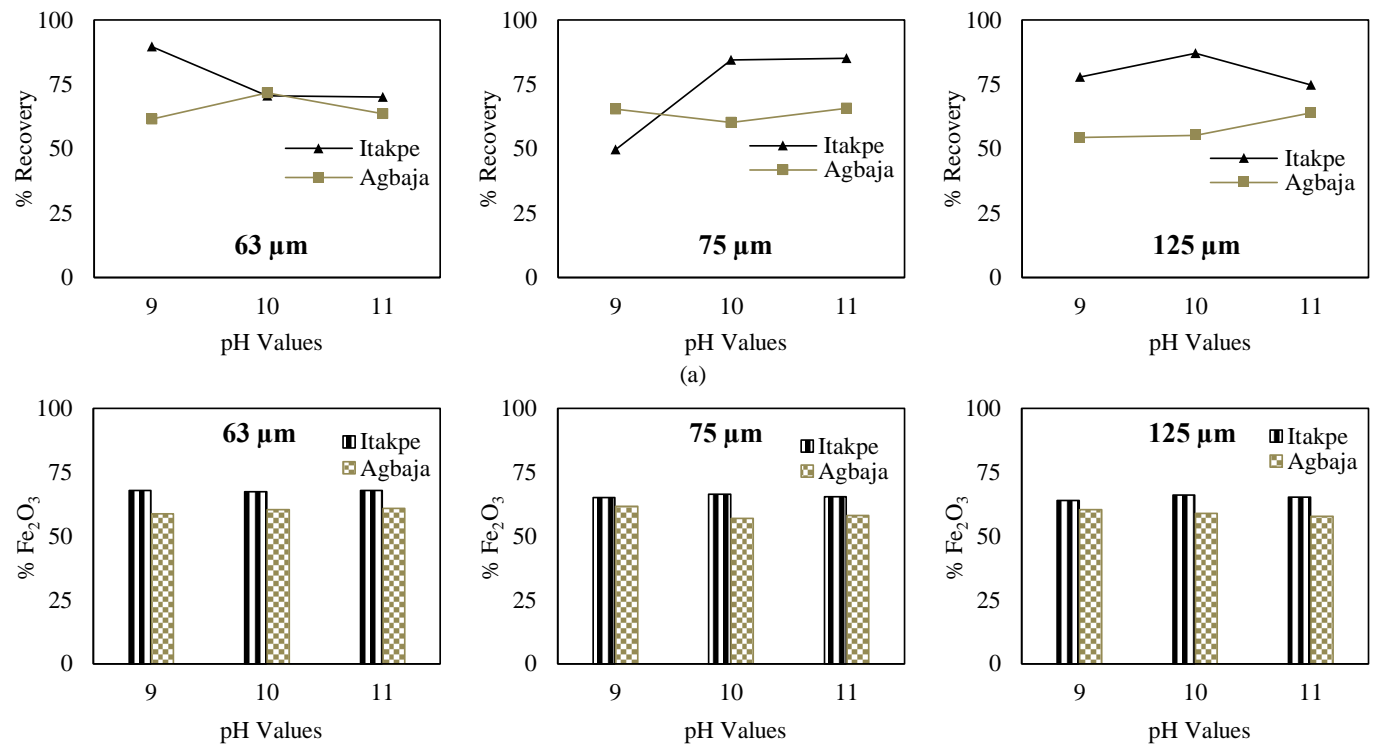

(b)

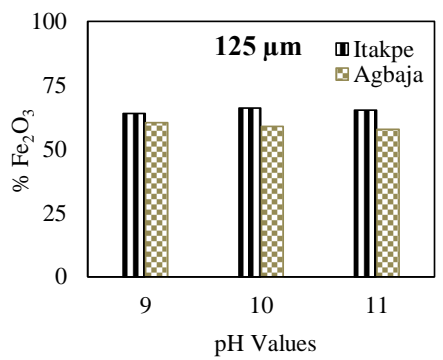

Fig. 8. Variation of (a) \% recovery, and (b) assay $\left(\% \mathrm{Fe}_{2} \mathrm{O}_{3}\right)$ of SEX-processed Itakpe and Agbaja iron ores with pH values at different particle sizes
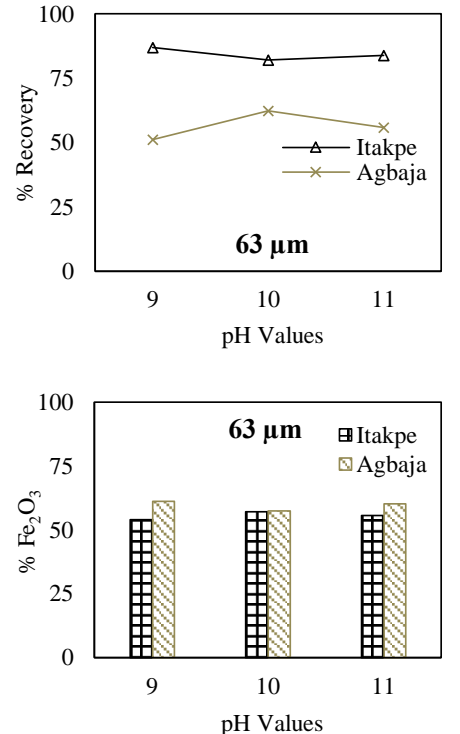

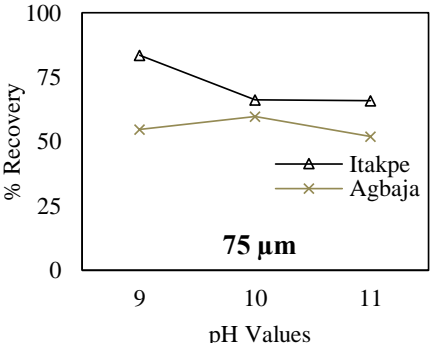

(a)

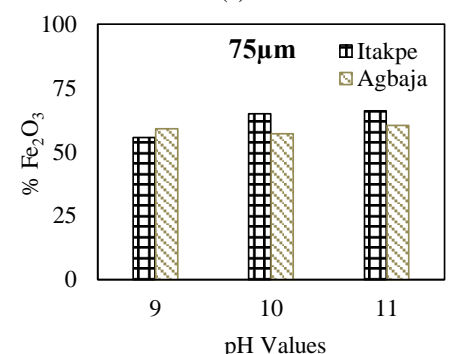

(b)
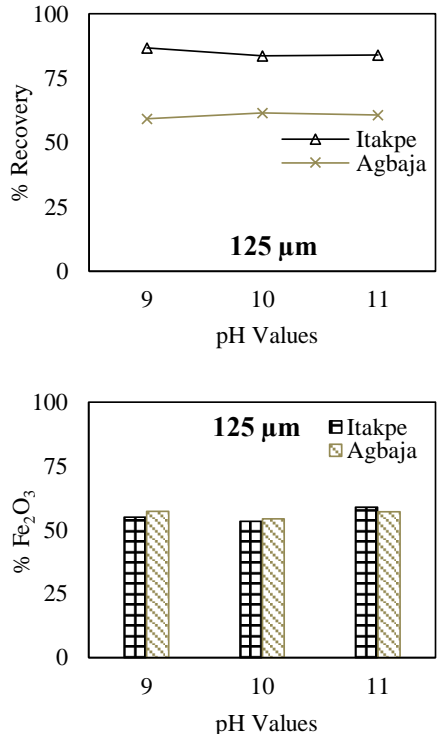

Fig. 9. Variation of (a) \% recovery, and (b) assay $\left(\% \mathrm{Fe}_{2} \mathrm{O}_{3}\right)$ of Oleic Acid-processed Itakpe and Agbaja iron ores with pH values at different particle sizes

\section{DISCUSSION}

\section{A. Mineralogical Features of Itakpe and Agbaja Iron Ores}

The results obtained for the petrological analysis of both ores are presented in Table I and Fig. 4. It can be deduced from Table I that Itakpe iron ore contains grains of quartz $\left(\mathrm{SiO}_{2}\right)$, sillimanite $\left(\mathrm{Al}_{2} \mathrm{SiO}_{5}\right)$, haematite $\left(\mathrm{Fe}_{2} \mathrm{O}_{3}\right)$, and other opaque minerals having modal counts of $34 \%, 4 \%$, and $62 \%$ respectively. While the mineral grains contained in Agbaja iron ore are quartz $\left(\mathrm{SiO}_{2}\right)$ and haematite $\left(\mathrm{Fe}_{2} \mathrm{O}_{3}\right)$ alongside other opaque minerals having a relative abundance of $58 \%$ and $42 \%$ respectively. This implies that the gangue mineral $\left(\mathrm{SiO}_{2}\right)$ is more predominant in Agbaja iron ore relative to the desired mineral (magnetite/haematite). Photomicrographs of Itakpe iron ore as shown in Fig. 4a reveal high concentrations of opaque mineral (possibly magnetite), haematite (occurring as reddish-brown stain within the rock), amphibole, and quartz. The reddish-brown specks within the rock depict a low degree of weathering which may not observable with the ordinary eye. However, the photomicrographs of Agbaja iron ore (Fig.4b) reveal ooids of iron silicate of diameter ranging from few microns to $2 \mathrm{~mm}$. The ooids shape vary from rounded to ellipsoid having different elongation degree. This observed surface morphology conforms to the findings in [12]. Also, the observable dark spots across the ore's matrix depict fragments of opaque minerals, mostly magnetite.

\section{B. Chemical Composition of Itakpe and Agbaja Iron Ores}

It is apparent from Table II that both ores have appreciable iron content. Itakpe iron ore assayed 36.18\% $\mathrm{Fe}_{2} \mathrm{O}_{3}, \quad 53.0 \% \quad \mathrm{SiO}_{2}, \quad 4.20 \% \quad \mathrm{Al}_{2} \mathrm{O}_{3}$, and other trace compounds while Agbaja iron ore contains $40.6 \% \mathrm{Fe}_{2} \mathrm{O}_{3}, 50$ $.5 \% \mathrm{SiO}_{2}, 4.50 \% \mathrm{Al}_{2} \mathrm{O}_{3}, 1.505 \% \mathrm{P}_{2} \mathrm{O}_{5}$ alongside other trace compounds. The major associated minerals in both ores are silica and alumina. The existence of phosphorus in Agbaja iron ore renders it non-economical despite its high iron content and rich reserve relative to Itakpe iron ore. These findings further affirm the petrological analysis result and also conforms to that obtained in literature [2][9][11]. 


\section{Liberation Studies of Itakpe and Agbaja Iron Ores}

Prior to the concentration of ore, it is pertinent to establish the particle size distribution and liberation characteristics of the ore. This informs the efficiency of comminution to segregate the mineral grains in the ore into different size ranges as well as liberate the desired mineral(s) from the associated minerals. As such, the results obtained from the liberation studies of both ores are presented in Fig. 5 and 6. Fig. 5 illustrates the plots of cumulative percentage (\%) weight retained and passing against sieve size for both ores while Fig. 6 shows comparatively, the iron content in size fractions of both ores. From Fig. 5a, it can be deduced that the trendlines of cumulative $\%$ weight retained and passing for Itakpe iron ore are mirror images having R-squared values of 0.983 and 0.9776 respectively, and they intercept at $180 \mu \mathrm{m}$. This size depicts the economic liberation size of Itakpe iron ore; that is, after comminution about $50 \%$ of the ore particles would have sizes below $180 \mu \mathrm{m}$. Fig. 5b illustrates the trendlines of cumulative $\%$ weight retained and passing obtained for Agbaja iron ore, both lines are also mirror-like having Rsquared values of 0.9771 each, and they intercept at $125 \mu \mathrm{m}$, which depicts the economic liberation size of Agbaja iron ore. The R-squared values obtained for both ores satisfy the standard R-squared value of $>75 \%$ which rates the significance of data for analysis [13]. Thus, the data obtained closely fit the regression lines/models with an accuracy of $>90 \%$. Comparing both economic liberation sizes, it can be implied that more energy will be expended to comminute Agbaja iron ore, which renders the ore less economical relative to Itakpe iron ore. From Figure 4, it is evident that the $\mathrm{Fe}_{2} \mathrm{O}_{3}$ content in Itakpe iron ore decreases from $+500 \mu \mathrm{m}$ to $-180+125 \mu \mathrm{m}$ while that of Agbaja increases progressively. It was also established that the size range having the highest $\mathrm{Fe}_{2} \mathrm{O}_{3}$ content for both ores was $75+63 \mu \mathrm{m}$, having a nominal aperture size of $75 \mu \mathrm{m}$. This size depicts the actual liberation size of both ores where the optimal concentration of $\mathrm{Fe}_{2} \mathrm{O}_{3}$ was achieved. It also falls within the size range suitable for the flotation of iron ores as documented in [7][12].

\section{Effects Varying Pulp pH and Particles Size on PAX- Processed Itakpe and Agbaja Iron Ores}

The results obtained from the flotation of both ores using PAX at different $\mathrm{pH}$ values and particle sizes are presented in Fig. 7. The efficiency of the process was measured in terms of $\%$ recovery and assay. Indeed, appreciable increment in the assays of both ores was achieved. Itakpe iron ore assaying $36.18 \% \mathrm{Fe}_{2} \mathrm{O}_{3}$ was enriched to a maximum of $67.66 \% \mathrm{Fe}_{2} \mathrm{O}_{3}$ while that of Agbaja increases from $40.6 \%$ $\mathrm{Fe}_{2} \mathrm{O}_{3}$ to a peak of $65.50 \% \mathrm{Fe}_{2} \mathrm{O}_{3}$. At particle size of $63 \mu \mathrm{m}$, Itakpe iron ore exhibited an upward trend in $\%$ recovery while a progressive increase in \% recovery was observed for Agbaja iron ore as the pulp pH was varied from 9 to 11 . Also, Itakpe iron ore exhibited a progressive increment in assay with increasing $\mathrm{pH}$ and vice versa for Agbaja iron ore. It was established that the optimal \% recovery for both ores was obtained at $\mathrm{pH} 11$. Thus, it can be inferred that the froth flotation of both ores using PAX at a particle size of $63 \mu \mathrm{m}$ is best carried out at more alkaline conditions. At particle size of $75 \mu \mathrm{m}$, the $\%$ recovery of both ores also increased progressively with increasing pulp $\mathrm{pH}$. Likewise, the assays exhibited the same trend as recorded for $63 \mu \mathrm{m}$. However, at $125 \mu \mathrm{m}, \%$ recovery and the assay of Itakpe iron ore increased extensively while that of Agbaja iron ore decreases. This implies that using PAX as the collector for the flotation of Itakpe iron ore would yield considerable recovery at more alkaline conditions for all considered particle sizes. While PAX is more suited for the flotation of Agbaja iron ore at particle sizes of 63 and $75 \mu \mathrm{m}$ also at more alkaline conditions ( $\mathrm{pH} 11)$.

\section{E. Effect of Varied Pulp pH and Particle Size on SEX- Processed Itakpe and Agbaja Iron Ores}

Fig. 8 presents the plots of $\%$ recoveries and assays obtained for both ores against the pulp $\mathrm{pH}$ for the particle sizes considered. It is quite apparent that significant enrichment was also obtained for both ores. Itakpe iron ore was enriched from $36.18 \% \mathrm{Fe}_{2} \mathrm{O}_{3}$ to $67.84 \% \mathrm{Fe}_{2} \mathrm{O}_{3}$ while Agbaja's assay rose to a maxima value of $61.63 \% \mathrm{Fe}_{2} \mathrm{O}_{3}$. At $63 \mu \mathrm{m}$, it is evident that the \% recovery of Itakpe iron ore decreases sharply as the $\mathrm{pH}$ value varies from 9 to 10 , and then slightly decreases at $\mathrm{pH} 11$. Conversely, the $\%$ recovery of Agbaja iron ore increases as the $\mathrm{pH}$ increases from 9 to 10 and then drops at $\mathrm{pH} 11$. The assays of both ores increased appreciably as the $\mathrm{pH}$ rises from 9 to 11 . The froth flotation of Itakpe iron ore at $75 \mu \mathrm{m}$ exhibited a sharp increase in \% recovery as the $\mathrm{pH}$ increases from 9 to 10, and then slightly rises at $\mathrm{pH} 11$. However, Agbaja iron ore exhibited a slight reduction and increment in \% recovery as the $\mathrm{pH}$ varies from 9 to 11 . Also, a slight increment in the assay of Itakpe and Agbaja iron ores was observed at $\mathrm{pH} 10$ and $\mathrm{pH} 9$ respectively. Furthermore, at $125 \mu \mathrm{m}$ Itakpe iron ore exhibited sloppy trend in \% recovery while the \% recovery of Agbaja iron ore rises progressively with increasing $\mathrm{pH}$. It can be implied that the $\%$ recoveries obtained for the different sets-of-conditions followed no regular pattern and they are quite below that obtained when PAX was utilized. Yet, SEX proves efficient in the flotation of Itakpe iron ore at a particle size of $63 \mu \mathrm{m}$ and $\mathrm{pH}$ of 9 owing to the optimal recovery $(89.79 \%)$ observed at this setof-conditions. Likewise, optimal recovery (71.72\%) was obtained for Agbaja iron ore at $63 \mu \mathrm{m}$ and $\mathrm{pH}$ of 10 .

\section{F. Effect of Varied Pulp pH and Particle Size on Oleic Acid-Processed Itakpe and Agbaja Iron Ores}

Fig. 9 illustrates the results obtained from the flotation of both ores using oleic acid at varying pulp $\mathrm{pH}$ and particle sizes. Similarly, appreciable enrichment of both ores was obtained using oleic acid. Processed Itakpe and Agbja iron ores assay a peak value of $66.01 \%$ and $61.07 \% \mathrm{Fe}_{2} \mathrm{O}_{3}$, respectively. Suffice to say that the \% recoveries of both ores exhibit converse slopes for each particle size as the pulp $\mathrm{pH}$ varies from 9 to 11 . In this regard, the effect of neutralization on the efficiency of the collector used (Oleic acid) and \% recovery was also pronounced as the pulp becomes more alkaline for all set-of-conditions [14]. This accounts for the observed reduction in \% recovery at higher $\mathrm{pH}$ values and the poor performance of oleic acid compared to other collectors used. Nonetheless, oleic acid also proved viable to the froth flotation of both ores. The optimal \% 
recovery of Itakpe iron ore was achieved at $63 \mu \mathrm{m}$ and $\mathrm{pH} 9$ while Agbaja's was obtained at the same size but $\mathrm{pH} 10$.

\section{CONCLUSION}

The need to revamp the steelmaking industry is imperative to promote significant technological advancement and economic sustainability. The prospect of this industry calls for a continuous and adequate supply of the major raw material, iron ore. Thus, the need to exploit other alternatives to Itakpe iron ore (the chief raw material for Ajaokuta Steel Company) such as the Agbaja iron ore is pertinent to curb the rapid decline of this deposit, and also promote the blending of both ores as feed for the processing plant. Therefore, on the premise of the findings in this work, further study is proposed to investigate the blending possibilities of both ores to produce super-concentrates.

\section{REFERENCES}

[1]. E. O. Akinrinsola, and J. I. Adekeye, "A geostatistical ore reserve estimation of the Itakpe iron ore deposit Okene, Kogi State," J. Min. Geol., vol. 20, no. 1, pp. 19-25, 1993.

[2]. A. S. AbdulRahman, "Susceptibility of Agbaja iron ore deposit in North Central Nigeria to magnetic separation," Journal of Modern Manufacturing Technology, vol. 4, no. 2, pp. 87-95, 2012.

[3]. O. O. Alabi, "Beneficiation of Ajabanoko iron ore deposit Kogi State, Nigeria using magnetic separation," International Journal of Civil, Mechanical and Energy Science, vol. 2, no. 2, pp. 91-93, 2016.

[4]. NIOMCo Project Report, vol. 2, pp. 1-10, 1980.

[5]. Raw Materials Research and Development Council (RMRDC), "Raw Materials update," A Bi-Annual Publication of the Raw Materials Research and Development Council, vol. 6, no. 1, pp. 9., 2005.

[6]. A. C. Araujo, P. R. M. Viana, and A. E. C. Peres, "Reagents in iron ores flotation," Mineral Engineering, vol. 18, pp. 219-224, 2005.

[7]. B. A. Wills, and T. J. Napier-Munn, Mineral Processing Technology, 7th ed. Pergamon Press, Oxford, 2006, ch. 12, 267-274.

[8]. N. Fardis, and I. Medhi, "Reagents types in flotation of iron oxide minerals: A review," Mineral Processing and Extractive Metallurgy Review, vol. 39, no. 2, pp. 89-124, 2018.

[9]. P. Olubambi, and J. Potgieter, "Effectiveness of gravity concentration for the beneficiation of Itakpe (Nigeria) iron ore achieved through jigging operation," Journal of Minerals and Materials Characterization and Engineering, vol. 4, pp. 21-30, 2005.
[10]. S. A. Ola et al., "Pilot-scale froth flotation studies to upgrade Nigerian Itakpe sinter grade iron ore to Mixres-grade superconcentrate," Journal of Minerals and Materials Characterization and Engineering, vol. 8, no. 5, pp. 405-416. 2009.

[11]. J. K. Odusote., A. A. Adeleke, S. A. Bankole, and A. A. Adeolu, "Preliminary characterisation of iron ores for steel making processes," Procedia Manufacturing, vol. 35, pp. 1123-1128, 2019.

[12]. P. L. Neymayer, E. S. George, and E. K. Antônio, "Effect of particle size range on iron ore flotation," REM: R. Esc. Minas, Ouro Preto, vol. 66 , no. 2, pp. 251-256, 2013.

[13]. M. Patricia, I. Jose, G. Cesar, and P. Oscar, "Assessing data analysis performance in research contexts: An experiment on accuracy, efficiency, productivity, and researchers' satisfaction," Data \& Knowledge Engineering, vol. 116, pp. 177-204, 2018.

[14]. R. K. Richard, "Froth flotation," Encyclopedia of Physical Science and Technology (Third Edition), pp. 219-234, 2003.

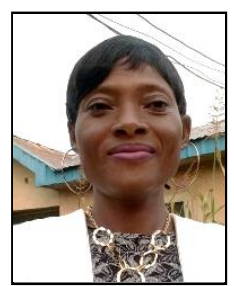

Mrs. Akande obtained her postgraduate diploma in mining engineering in 2010 from the Federal University of Technology, Akure (FUTA), Ondo State, Nigeria. In 2019, she obtained her master of engineering degree in mining engineering from FUTA. She is currently the Assistant Chief Technologist at the Department of Mining Engineering, FUTA. Her research interests include mineral identification, mineral beneficiation, hydrometallurgy, and process route optimization. Mrs. Akande is a certified member of APWEN, COMEG, NATE, and NSME.

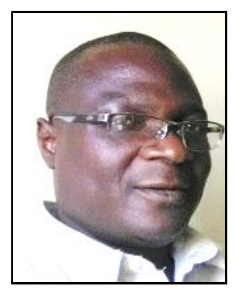

Engr. Dr. Oladunni Oyelola Alabi is a Ph.D. holder in metallurgical and materials engineering from Ahmadu Bello University, Zaria. He is currently a lecturer at the Department of Metallurgical and Materials Engineering, Federal University of Technology, Akure, Ondo State, Nigeria. Engr. Dr. Alabi is a certified member of COREN, NSE, and NMS.

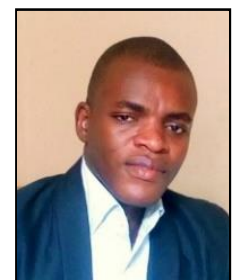

Mr. Temitope Amos Olatunji obtained his bachelor of engineering degree in metallurgical and materials engineering from the Federal University of Technology, Akure, Ondo State, Nigeria. He is currently a graduate scholar and a prospective applicant for funding to pursue either a MSc. or MPhil/Ph.D. program in materials science and engineering. His research trajectory focuses on mineral $/$ material processing and the development of advanced materials. Mr. Olatunji is a certified 